\title{
Windows, Bridges and Mirrors: Building Culturally Responsive Early Childhood Classrooms through the Integration of Literacy and the Arts
}

\author{
Paula G. Purnell, ${ }^{1,2}$ Parveen Ali, ${ }^{1}$ Nurun Begum, ${ }^{1}$ and Marilyn Carter $^{1}$
}

\begin{abstract}
This article investigates how instructors can utilize the integration of early literacy skills and the arts to cultivate the appreciation and celebration of cultures in early childhood classrooms. The theoretical framework is developed through three personal accounts establishing a rationale for the importance of a viable home to school connection for young children. Finally, the suggested activities support the transference of theory into classroom practice.
\end{abstract}

KEY WORDS: culture; cultural identity; culturally responsive classrooms; home culture; early literacy; learning environment; arts integration; affective needs; content integration; multicultural literature.

Responding to the needs of an increasingly diverse student population is both a great opportunity and a great challenge for educators. Today, early childhood teachers must be well prepared with an array of skills, attitudes, and knowledge necessary to undertake the immense responsibility of creating culturally responsive classrooms. Effective teachers must find inventive ways to utilize the limited resources and time available, not only to ensure their students' academic achievement, but also to ensure the social and emotional growth of children from very divergent backgrounds.

The purpose of this article is to provide strategies and ideas for building culturally responsive early childhood classrooms through the integration of literacy and the arts.

Three reflective accounts which illustrate the cognitive, social and emotional benefits culturally responsive learning environments will be presented.

\footnotetext{
${ }^{1}$ Professional Studies in Education, Indiana University of Pennsylvania, 570 South Eleventh Street, Indiana, PA 15705, USA.

${ }^{2}$ Correspondence should be directed to Paula G. Purnell, Professional Studies in Education, Indiana University of Pennsylvania, 570 South Eleventh Street, Indiana, PA 15705, USA; e-mail: p.g.purnell@iup.edu
}

Arts integration (AI) will be discussed and examples of art/literacy integrated activities that address various stages of early literacy development will be offered. Exemplars of multicultural materials will be provided, along with lesson ideas designed to bridge the gap between students' home cultures and the classroom.

\section{ACCOUNT 1}

Neha was an intelligent, shy, slightly built, five year-old whose parents immigrated to the USA from Asia. Soon after enrolling Neha in kindergarten, her mother received a conference request from her teacher who was concerned that Neha was daydreaming in class. As evidence, she produced Neha's paper work, which was nothing but scribbles. Neha's mother was upset and confused. Her daughter had not experienced any such problems previously.

Perhaps Neha's teacher had failed to notice that at lunchtime and in the hallways, Neha's classmates teased her relentlessly - taunting, "Are you Chinese or are you Mexican?" Neha also felt out of place on the playground where the more athletic children climbed monkey bars and played games that were unfamiliar to Neha. Here, too, the other children noticed Neha's differences and the teasing continued. 
At the end of the year, all of the children, except a few, received some kind of special recognition during the graduation ceremony. Neha was one of the very few.

Imagine how Neha's first school experience in the United Stated might have been different if her kindergarten teacher had possessed the knowledge and strategies needed to create a culturally responsive classroom. Neha would have felt welcomed and appreciated for the wonderful and unique contributions she could bring to the curriculum. The other children would have been invited to explore the stories, art, music, and dance of Neha's home culture. Together, they would learn to celebrate each student's unique life experiences, discovering, along the way, that the very things that make them each so different, are also what makes them each so very special.

Children's affective needs - the need for cognitive, emotional and intellectual safety - must be met in order for children to flourish academically. It is not unusual for children who feel insecure or socially isolated to shut down cognitively. Emotionally stressful homes and/or school environments have detrimental effects on students' academic achievement, while schools that address and support students' affective needs can significantly enhance learning (Gilbert \& Morawski, 2005; Janssen, Braaksma, \& Rijlaarsdam, 2005). Neha's story dramatically illustrates how social stress and cultural ambivalence can interrupt the development of early literacy skills.

Educational theorists have sought to better understand the complex influence of culture on learning (Bruner, 1996; Cambourne, 1988). Yet, a definitive definition of culture remains elusive. Sir E.B. Taylor's (1871) definition of culture states that "it is the complex whole which includes the knowledge, belief, arts, morals, law, custom, and any other capabilities and habits acquired by man as a member of society" (p. 1). Social scientists continue to amend and extend Taylor's definition (Barnard \& Spencer, 1996), but it is generally agreed that culture is acquired through associations and interactions among family members and across communities, both large and small. These interactions and associations are the foundation upon which we build our interpretation of the world. According to learning theorist Jerome Bruner, the construction of knowledge is never point-of-viewless, in fact, "Cultural products, such as language and other symbolic systems, mediate thought and place their stamp on our representations of reality" (Bruner, 1991, p. 3). The educational value of culturally responsive teaching becomes apparent in view of the vital role that culture plays in how children interpret and respond to the world around them.

A culturally responsive curriculum is designed to recognize and accept the wide range of cultural differences that exist in every classroom. Whether in a large, multiethnic urban setting or in a small, rural homogeneous classroom, students come to school with an array of life experiences which have been lived within the context of their unique cultural setting. Culturally responsive teaching employs a pedagogy which "accommodates the dynamic mix of race, ethnicity, class, gender, region, religion, and family that contribute to every student's cultural identity" (Wlodkowski \& Ginsberg, 1995, p. 17).

Teachers dedicated to encouraging the development of positive cultural identities for all students:

- Stress respect for diversity in order to engage the motivation of all learners.

- Create safe, inclusive, caring and respectful learning environments.

- Integrate culturally responsive teaching practices into all disciplines.

- Transform the curriculum to promote social justice and equity (Phuntsog, 1998).

The discriminatory behavior towards Neha by her peers happened because the children in Neha's kindergarten had not learned how to respond to differences in a positive way. In a culturally responsive classroom, difference is not just tolerated; it is welcomed and celebrated, creating an atmosphere of unconditional acceptance for all children.

\section{ACCOUNT 2}

\footnotetext{
Ellen's parents divorced when she was an infant. Her mother's drug addiction led to placement in various residential treatment programs until finally Ellen's grandmother was granted legal custody of Ellen. Ellen bitterly recalls her earliest literacy experiences. "I remember being in reading class and seeing the words "father" or" mother" in a story - it felt like a dagger in my heart." She knew that soon the discussion would turn to families, with other children talking and sharing happily about their parents and their siblings. Now, as an adult, Ellen realizes that there were probably other students in her school, maybe even in her own classroom, who also came from nontraditional families. But Ellen only remembers feeling "totally alone in the universe."
}

The first of the five dimensions of multicultural education defined by James Banks is Content 
Integration. This dimension, "deals with the extent to which teachers use examples and content from a variety of cultures and groups to illustrate key concepts, principles, generalizations, and theories in their subject area or discipline (Banks, 2006, p. 8). Since the early 1960's, multicultural education advocates have recognized the importance of providing educational materials that respectfully and accurately represent the students' own ethnic and cultural backgrounds.

Culturally relevant stories and activities help young children connect academic lessons to their own life experiences, making the content more meaningful. Opportunities to share different life experiences also help to create a sense of community among diverse learners. As a young child, Ellen never saw her own life experiences illustrated in the pages of the stories read in school. Perhaps her teacher simply didn't know how to address Ellen's family situation and so she did what many people do when they are unsure - she avoided the subject. Ironically, there was no need for Ellen to feel ostracized by her classmates simply because she did not live in a traditional nuclear family. Ellen was very lucky to have a loving grandmother and a supportive extended family. Imagine how empowered Ellen might have felt if one day her teacher had included a story that focused on a little girl who lived with her wonderful grandmother.

From the earliest age we organize our experiences and our memories mainly in the form of narratives and stories (Bruner, 1966). Early childhood education theorists have long argued that in order for literacy learning to take place, the content must have meaning for the child (Dewey, 1916; Froebel, 1887/1974; Pestalozzi, 1894). Many educators are concerned, however, that the current focus on systematic and explicit phonics instruction reduces opportunities for meaningful literacy engagement within the classroom (Guthrie, 2004). When teachers incorporate culturally relevant reading materials in their literacy lessons, they can achieve two important goals at once; they engage the learner in the concepts being taught on a more meaningful and personal level; and they create an inclusive learning environment. For young children multicultural stories can act as a mirror, reflecting and validating the students' cultural identity. For children from diverse backgrounds, these stories are windows into a new realm of experiences (Cox \& Galda, 1990).

\section{ACCOUNT 3}

\begin{abstract}
Alex was in third grade. His mother was from China and his father was Anglo-American. The biggest annual celebration in Alex's family was lunar New Year. This year Alex's mother offered to come to school to tell his class about their New Year traditions. But Alex was very resistant. He had never mentioned his Chinese heritage in school, "I'm not sure I want them to know," he said with downcast eyes. Besides, his mother's English was not very good, and he worried the kids might make fun of her.
\end{abstract}

\begin{abstract}
Alex waited nervously all morning for his mother's arrival. It didn't take long for him to realize, however, that his fears were unfounded. His mother proudly told his class about her childhood in China and they asked a lot of questions. She brought each student a hongboa, which is a small red envelope that holds New Year money. Alex's grandmother had made jiaozi, little dumplings filled with meat and vegetables, for the class and the students loved them! Finally, his mother demonstrated Chinese calligraphy and made a Chulian, a bright red banner decorated with good wishes for the New Year, and hung it on their classroom door. Later in the week the class listened to music from China and watched a video of traditional lion dancers. The teacher hung a world map on the wall and put a pin in Beijing, the capitol of China where Alex's mother was born. She also sent a flyer home inviting family and friends of students to share their heritage with the class.
\end{abstract}

Elliot Eisner (2005) reminds us that the arts make three things possible. They provide opportunities to think and learn in new ways; they allow us to communicate when other forms of language fail; and they enrich the spaces in which we live. When we apply these benefits to the classroom we broaden the scope of our teaching to include all of our students' senses, learning styles, intelligences, and backgrounds. The arts are both a method of communication and one of the most important ways that people develop a sense of cultural and personal identity (Goldberg, 2006). For young children, the arts - drawing, moving, singing, and creative play - are also a unique language (Isenberg \& Jalongo, 2006). Effective early childhood teachers draw on children's natural inclination to be storytellers, actors, and artists to engage students in learning and enhance the development of literacy skills.

Research has found a significant correlation between arts participation and academic achievement. 
The greatest gains were identified among students in the lowest socioeconomic status group, and for those children described as "at-risk" (Catterall, Chapleau, \& Iwanaga, 1999). In addition to academic improvement, the arts have been shown to have a positive effect on the social and emotional development of children. The arts nourish important sensory, attentional, cognitive, emotional, and neurobiological systems. Artsrich programs develop leadership skills, self-esteem and cooperation (Camilleri \& Jackson, 2005).

Alex's mother was able to bridge the distance in Alex's bicultural life by sharing the traditional arts of his home culture. His teacher was able to build on the students' enthusiasm to enhance and extend the curriculum. When students are engaged in learning subject content in meaningful ways they learn and retain more information.

Arts integration (AI) occurs when teachers identify specific skills, concepts, or ideas in a core subject - such as math, reading, science or social studies - which can be enhanced, reinforced, illustrated or examined through a parallel arts experience (Rabkin \& Redmond, 2006). To create a literacy/arts integrated lesson, teachers need to first identify a specific literacy skill, such as letter recognition, and then develop an arts-based learning experience that can enhance that skill. For example, children's ability to create shapes and textures can be enhanced through the tactile activity of working with clay. Alphabetic awareness can be enhanced when children use clay to shape letters. The following example of an art/literacy activity incorporates multicultural literature and utilizes the Caldecott Honor Book, When Clay Sings written by Byrd Baylor (1972) and illustrated by Tom Bahti. It provides a beautiful and authentic introduction to Native American heritage as well as to the art of pottery.

\section{MULTICULTURAL ARTS/LITERACY ACTIVITIES}

\section{Using Clay to Enhance Alphabetic Principle}

Interactive Read Aloud:When Clay Sings, written by Byrd Baylor, illustrated by Tom Bahti

Summary: Pieces of broken pots are scattered over the desert hillsides of the Southwest. The Indians there treat them with respect - "Every piece of clay is a piece of someone's life," they say. And the children try to imagine those lives that took place in the desert they think of as their own. Clay has its own small voice, and sings. Its song has lasted for thousands of years. Byrd Baylor's prose-poem, as simple and powerful as the clay pots, sings too. (Publisher notes on Baylor, 1972)

Activity: Display and discuss illustrations or samples of Native American pottery. Explain that there are many methods for making pottery, including pinch pots, and coiling. Distribute a fist-size piece of clay to each student and demonstrate the process of rolling a piece of clay into a long "snake" shape. The rope of clay can be wrapped into a tight coil to create a coil pot. Complete instructions for Native American Coil Pot Lesson Plan (2nd grade) are available at: http://www.dickblick.com/multicultural/ coilpots/.

Ropes of clay can also be used to create letter shapes. Artist Keith Haring's imaginative, kidfriendly website, Haring Kids, includes a teachersubmitted art/literacy lesson, titled Alphabet Sculpture Scene. This activity allows students to kinesthetically explore the connection between shapes, letters, sounds, symbols, and meaning. Examples of student work and the complete lesson are available at: http://www.haringkids.com/lessons/ envs/live/htdocs/lesson116.htm

\begin{tabular}{|c|c|c|c|c|}
\hline $\begin{array}{l}\text { Developmental } \\
\text { Stage }\end{array}$ & $\begin{array}{c}\text { PA Academic } \\
\text { Standard } \\
\text { in Literacy }\end{array}$ & $\begin{array}{c}\text { PA Academic } \\
\text { Standard in Art }\end{array}$ & $\begin{array}{c}\text { Essential } \\
\text { Components }\end{array}$ & $\begin{array}{c}\text { Book Title and } \\
\text { Author }\end{array}$ \\
\hline $\begin{array}{l}\text { Emergent/ } \\
\text { beginning }\end{array}$ & $\begin{array}{l}\text { 1.1.G Knowledge of } \\
\text { letters and their sounds } \\
\text { (alphabetic principles) } \\
\text { 1.1.H Decode words } \\
\text { (phonemic awareness) }\end{array}$ & $\begin{array}{l}\text { 9.1.F Use elements } \\
\text { of shape and } \\
\text { texture } \\
\text { 9.1.Q Analyze } \\
\text { works of } \\
\text { art in cultural } \\
\text { and historical } \\
\text { context }\end{array}$ & $\begin{array}{l}\text { Recognize and create shapes; } \\
\text { explore sounds and symbols; } \\
\text { use arts materials (clay) and } \\
\text { various tools to create texture }\end{array}$ & $\begin{array}{l}\text { When Clay Sings, } \\
\text { written by } \\
\text { Byrd Baylor }\end{array}$ \\
\hline
\end{tabular}

Pennsylvania's Standards for Kindergarten, 2005 


\begin{tabular}{lllll}
\hline $\begin{array}{l}\text { Developmental } \\
\text { Stage }\end{array}$ & $\begin{array}{l}\text { PA Academic } \\
\text { Standard in } \\
\text { Literacy }\end{array}$ & $\begin{array}{l}\text { PA Academic } \\
\text { Standard in Art }\end{array}$ & $\begin{array}{l}\text { Essential } \\
\text { Components }\end{array}$ & Book Title and Author \\
\hline Emergent & $\begin{array}{l}\text { 1.1C Discriminate } \\
\text { sounds and words }\end{array}$ & $\begin{array}{l}\text { 9.2.B Identify common } \\
\text { themes and patterns }\end{array}$ & $\begin{array}{l}\text { Same/different; } \\
\text { sort and classify }\end{array}$ & $\begin{array}{l}\text { We Are All Alike, } \\
\text { We Are All Different, } \\
\text { by Cheltonham Elementary } \\
\text { School Kindergartners }\end{array}$ \\
\hline
\end{tabular}

Pennsylvania Standards for Kindergarten, 2006

\section{Exploring Difference with People Portraits}

Interactive Read Aloud: We Are All Alike ... We Are All Different, by Cheltonham Elementary School Kindergartners.

Summary: This book, written by children for children, reinforces multicultural and anti-bias learning and appreciation. With original drawings and lyrical words, the children in Rosalind Goldberg's kindergarten class at Cheltenham Elementary School in Pennsylvania share the ways they look and feel, the games they play, the foods they like, the homes they live in, and the families they live with, concluding that, "We are all alike. We are all different. We are a family." (Summary by Scholastic Books)

\section{Activity: People Portraits}

Mixable multicultural paints allow students to discover and compare their unique skin tones. Starting Small: Teaching Children Tolerance, a video offered by the Southern Poverty Law Center free of charge to educators, features a kindergarten class making "People Portraits" and learning some of the ways in which they are each unique and special.

Multicultural paints sets are available at:

Crayola Multicultural Paint Set: http://edushop. edu4kids.com/catalog/product_info.php?products_id = 683
Colorations, Colors Like Me, Multicultural Paints

http://www.discountschoolsupply.com/Product/ ProductDetail.aspx? product $=3677 \& \mathrm{mlc}=$

Starting Small: Teaching Children Tolerance can be ordered through the Teaching Tolerance website at:

http://www.tolerance.org/teach/resources/index.jsp

\section{Recipes for Celebrating Our Heritage}

Interactive Read Aloud: Jalapeño Bagels, by Natasha Wing, illustrated by Robert Casilla

Summary: When Pablo must bring something to share for his school's International Day, he considers several items from his family's bakery. But his mother's Mexican pan dulce, empanadas, and chango bars don't do the trick. His father's bagels and challah bread are appealing, but not quite right either. Then the boy helps to make the family specialty, Jalapeno Bagels - a joint creation from the cultures of both parents and decides that it is the perfect contribution: “...a mixture of both of you. Just like me." (Publisher notes on Wing, 1996)

\section{Activity: Classroom Cookbook}

Creating a class cookbook provides an opportunity to invite parents, friends, and extended family to participate in a literacy activity. Celebrate the completion of the book with a Classroom Cultural

\begin{tabular}{llll}
\hline $\begin{array}{l}\text { Developmental } \\
\text { Stage }\end{array}$ & $\begin{array}{l}\text { PA Academic } \\
\text { Standard in } \\
\text { Literacy }\end{array}$ & $\begin{array}{l}\text { PA Academic } \\
\text { Standard in Art }\end{array}$ & Essential Components \\
\hline Early fluent & $\begin{array}{l}\text { 1.4.B Write } \\
\text { informational } \\
\text { pieces } \\
\text { (instructions) }\end{array}$ & $\begin{array}{l}\text { 9.2.K Explain and } \\
\text { analyze } \\
\text { traditions }\end{array}$ & $\begin{array}{l}\text { Recognize sequence; } \\
\text { examine cultural heritage and } \\
\text { explore traditions }\end{array}$ \\
\hline
\end{tabular}

Pennsylvania Academic Standards K-12 
Fair and ask everyone bringing a dish to share. Include traditional music, dance and student artwork in festivities.

Resources: The Parent's Choice Approved book, The Kids' Multicultural Cookbook: Food \& Fun Around the World (Williamson Kids Can! Series) written by Deanna F. Cook and illustrated by Michael P. Kline, can be an excellent resource for beginning a culinary class discussion. Another book that addresses bicultural family life is Thanksgiving at Obaachan's by Janet Mitsui Brown, which explains how a Japanese-American family incorporates their ethnic foods into a traditional American Thanksgiving meal. This book is recommended for grades $2-4$.

\section{CONCLUSION}

We construct our knowledge of the world through the lens of our individual life experiences. In this sense, every classroom is multicultural, since no two life stories are exactly the same. Children feel emotionally secure when they find themselves, and those they love, positively represented in curriculum materials. Culturally responsive teachers create learning environments that respectfully reflect each child's home culture, while inviting children to accept and explore cultures which are unfamiliar to them. By practicing content integration and including high quality multicultural literacy materials as part of regular classroom activities, teachers model interest in, and acceptance of, difference.

The arts are a valuable educational tool. Arts integration can create new and meaningful connections to lesson content, expand students' understanding of other cultures, and help to promote the development of healthy cultural identities - for as Jerome Bruner says, "Life is a work of art, probably the greatest one we produce" (Bruner, 1999, p. 7).

\section{Children's Books Cited}

Baylor, B. (1972). When Clay Sings. New York: Atheneum Books for Young Readers.

Brown, J. M. (1994). Thanksgiving at Obaachan's. Chicago: Polychrome Publishing.

Cheltenham Elementary School Kindergartners (2002). We are all alike ... we are all different. New York: Scholastic.

Cook, D. F. (1995). The kids' multicultural cookbook: Food \& fun around the world. Charlotte, VT: Williamson Publishing Company.

Wing, N. (1996). Jalapeno bagels. New York: Atheneum Books for Young Readers.

\section{Online Resources}

Deslaurier, D. Clay alphabet sculpture scenes. Retrieved August 20, 2005, from http://www.haringkids.com/lessons/envs/live/ htdocs/lesson116.htm.
McGovern, M. (Producer). (1997). Starting small: Teaching children tolerance [Video Cassette]. (Available from Southern Poverty Law Center, 400 Washington Avenue, Montgomery, AL 36104)

Pietropola, A. (1992). Native American coil pots lesson plan. Retrieved January 10, 2006, from http://www.dickblick.com/ multicultural/coilpots/.

\section{REFERENCES}

Banks, J. A. (2006). Cultural diversity and education: Foundations, curriculum and teaching. Boston: Pearson Education.

Barnard, A., Spencer, J. (Eds.) (1996). Encyclopedia of social and cultural anthropology. New York: Routledge.

Bruner, J. (1966). Toward a theory of instruction. Cambridge, MA: Belkapp Press.

Bruner, J. (1991). The narrative construction of reality. Critical Inquiry, 18(1), 1-20.

Bruner, J. (1996). The culture of education. Cambridge, MA: Harvard University Press.

Bruner, J. (1999). Narratives of aging. Journal of Aging Studies, 13(1), 7-10.

Catterall J. S., Chapleau R., \& Iwanaga J. (1999). Involvement in the arts and human development. In: Fiske E. B. (Ed.), Champions of Change: The impact of the arts on learning (pp. 1-18). Washington, DC: Arts Education Partnership.

Cambourne, B. (1988). The whole story: Natural learning and the acquisition of literacy in the classroom. New York: Aston Scholastic.

Camilleri, V., \& Jackson, A. (2005). Nurturing excellence through the arts. Educational Leadership, 62(6), 60-64.

Cox, S., \& Galda, L. (1990). Multicultural literacy: Mirrors and windows on a global community. The Reading Teacher, 43(8), $582-589$

Dewey, J. (1916). Democracy and education. New York: Macmillan.

Eisner, E. (2005). Opening a shuttered window: An introduction to a special section on the arts and intellect. Phi Delta Kappan, $87(1), 8-10$.

Froebel, F.W. (1887/1974). The educaton of man. New York: D. Appleton \& Company (Original work published in 1826) (W.N. Hailman, Trans.).

Gibert, J., \& Morawski, C. (2005). Stress coping for elementary school children: A case for including lifestyle. Journal of Individual Psychology, 61(4), 314-328.

Goldberg, M. (2006). Integrating the arts: An approach to teaching and learning in multicultural and multilingual settings (3rd ed.). Boston: Allyn \& Bacon.

Guthrie, J. T. (2004). Teaching for literacy engagement. Journal of Literacy Research, 36, 1-30.

Isenberg, J. P., \& Jalongo, M. R. (2006). Creative thinking and artsbased learning: Preschool through fourth grade (4th ed.). Upper Saddle River, NJ: Merrill/Prentice Hall.

Janssen, T., Braaksma, M., \& Rijlaarsdam, G. (2005). Literary reading activities of good and weak students: A think aloud study. European Journal of Psychology of Education, 21(1), 35-52.

Pestalozzi, J. H. (1894). How Gertrude teaches her children. London: Swan Sonnenschein.

Phuntsog, N. (1998). The magic of culturally responsive pedagogy: In search of Genie's lamp in multicultural education. Paper presented at the annual meeting of the American Research Association (San Deigo, CA. April 13-17, 1998). (ERIC Document Reproduction Service No. ED 420 632).

Rabkin, N., \& Redmond, R. (2006). The arts make a difference. Educational Leadership, 63(5), 60-64.

Taylor, E. B. (1871). Primitive culture 1London: John Murray.

Wlodkowski, R. J., \& Ginsberg, M. B. (1995). A framework for culturally responsive teaching. Educational Leadership, 53(1), $17-21$. 
Copyright of Early Childhood Education Journal is the property of Springer Science \& Business Media B.V. and its content may not be copied or emailed to multiple sites or posted to a listserv without the copyright holder's express written permission. However, users may print, download, or email articles for individual use. 